\title{
The Turn to Contractual Responsibility in the Global Extractive Industry
}

\author{
James GATHII* and Ibironke T ODUMOSU-AYANU**
}

\begin{abstract}
This article argues that there is a newer model of contracting for natural resources that expands the potential for corporate responsibility towards those adversely affected by business activities. It lays out the conceptual roadmap and justification underlying these shifts and changes in contracting for natural resources. The article calls for a renewed focus in exploring enforcement of corporate obligations for impacts to individuals and communities within a contractual framework. Examples of this type of arrangements include contracts that can be construed to allow third parties to sue on a contract; community development agreements; contracts between investors and communities; environmental contracts; human rights deeds, and investor-state-local community contracts (tripartite contracts). These contractual forms demonstrate that the law of contract has evolved from the nineteenth century idea that contracts merely protect the rights of investors without much concern for those who are directly affected by extractive industry operations. By including affected communities, indigenous communities, and others, these new contractual forms demonstrate that investors and governments are trustees and that extractive resources must be mobilized for the benefits of their publics. In so doing, we map this turn to contracts between multiple parties in the resource extraction context, and argue that it affirmatively demonstrates real potential to address or mitigate the absence of remedial and responsibility regimes for the adverse impacts of extractive industry activities on individuals and communities.
\end{abstract}

Keywords: contracts, human rights, investors, natural resources, remedies

\section{INTRODUCTION}

Contractual regimes as an additional option for corporate liability are currently under-emphasized in the literature on corporate responsibility for human rights violations. Nevertheless, the turn towards contractual regimes has real potential to address or mitigate the absence of remedial regimes for the adverse impacts of extractive industry activities on individuals and communities. This article argues that there should be a renewed focus on exploring the enforcement of corporate obligations for impacts on individuals and communities within a contractual framework. Using specific examples

* Wing-Tat Lee Chair in International Law and Professor of Law, Loyola University Chicago School of Law.

** Associate Professor, College of Law, University of Saskatchewan. Thanks to the Social Sciences and Humanities Research Council (Canada) and the Law Foundation of Saskatchewan for providing research funds for aspects of the research presented in this article and to Olufunmi Ayotunde and Janelle Souter for excellent research assistance. 
of contracts and contractual clauses in the extractive industry, we show that there is an under-examined and emerging shift in liability and responsibility regimes for corporate actors in the extractive industry.

The article proceeds as follows. Part II provides the conceptual overview of the contractual turn to corporate responsibility in the extractive industry. It examines how new forms of contracting have resulted in a newer model of contracting for natural resources and discusses the conceptual shifts that have been set in motion by these changes. In addition, it lays out the conceptual roadmap and justification underlying these shifts and changes. Part III examines non-binding approaches such as the Global Compact and the UN Guiding Principles on Business and Human Rights (Guiding Principles) ${ }^{1}$ in addressing adverse consequences that arise in natural resource extraction. This part also examines the historical antecedents of contractual relations between resource rich sovereigns and investors. Part IV then discusses corporate actors as moral agents with responsibilities such as those contained in the contractual forms discussed in Part V. By recognizing that the purposes of contract doctrine go beyond the narrow individual interests of the contracting parties, the larger societal goals that natural resource contracts serve become visible in these debates.

Part V of the article offers a detailed elaboration of the contractual turn in the natural resource sector. It traces the explosion of a variety of contractual regimes that go beyond those between sovereigns and investors and that include: contracts between investors and communities, environmental contracts, human rights deeds, and investor-statelocal-community contracts (tripartite contracts). In so doing, it maps the turn to contracts between multiple parties in the resource extraction context, and argues that this turn affirmatively demonstrates real potential to address or mitigate the absence of remedial and responsibility regimes for the adverse impacts of extractive industry activities on individuals and communities. Part VI concludes with an analysis of the strengths and limitations of contemporary extractive industry contracts as mechanisms for determining and addressing responsibility in the global extractive industry.

\section{Contracts Do Not Exist IndePendently of Their SOCIAL CONTEXT}

The contractual shift that we trace in this article demonstrates that natural resource extraction contracts arise from their social context. The growth of contractual regimes beyond those between governments and investors in the extractive industry shows that newer contractual forms arise not merely from individual autonomy as expressed through form and exchange but also through other means such as justified reliance. ${ }^{2}$ Hence, like legal realists writing about a century ago, ${ }^{3}$ we argue that community norms and shared understandings such as those embodied in international human rights norms are embedded

\footnotetext{
1 UN Human Rights Office of the High Commissioner, 'Guiding Principles on Business and Human Rights: Implementing the United Nations "Protect, Respect and Remedy" Framework', HR/PUB/11/04 (2011), http://www. ohchr.org/Documents/Publications/GuidingPrinciplesBusinessHR_EN.pdf (accessed 1 August 2015).

2 Lon Fuller, 'Consideration and Form' (1941) 41 Columbia Law Review 799, 821-22.

3 Ibid, 810-13.
} 
in natural resource contracts between resource-rich governments and investors. For realists, binding agreements were not merely the outcome of individual autonomy, but rather outcomes from the social context in which the contract was formed. ${ }^{4}$ We proceed from the groundwork laid by theorists for whom contract law was a delegation of public power to private actors rather than an expression of neutral private institutions or private ordering.

Our understanding of contracts rejects notions of natural resource contracts as private arrangements arising from promise and exchange between contracting parties who are otherwise disaggregated and are only bound together by contracts. Contracts in this sense are a 'morally contingent type of private legislation'. 5 For us, contracts cannot be regarded as just merely because parties to a contract reached a genuine agreement between themselves of their own free will. Given the evidence we extensively lay out in part $\mathrm{V}$, we reject the premise that natural resource contracts are valid merely because they reflect the free will or individual autonomy of the contracting parties. This is in large part because understanding these contracts as a form of private ordering precludes judging their validity by external or extrinsic criteria such as international human rights, notions of justice, fairness, or environmental norms, and the concerns of citizens adversely affected by extraction activities which have in turn propelled the emergence of new contractual regimes that capture the holistic picture of all parties affected by extractive activities. Even leaving aside the external context beyond the privity of contracting parties, doctrines such as duress, unconscionability, and misrepresentation demonstrate the limits within contract law that are designed to ensure that bargains are voluntary as well as fair and that contracting parties have adequate information. ${ }^{6}$

We, however, go beyond these internal limitations of contract law and demonstrate with evidence of newer contractual forms that the formation of contracts in the extractive industries can no longer be understood to exclude communities and individuals for whose benefit governments hold such extractive resources. This contemporary contractual landscape shows that the law of contract in the extractive industries context cannot in the twenty-first century continue to be based on legal theories developed in the nineteenth century according to which 'any private actor who is good enough to open his property to the public by putting it into the lines of commerce should not be discouraged by imposing even the most limited of social duties on his conduct' ${ }^{7}$ The law of contract must do more than merely protect the rights of investors without much concern for those directly affected by the operations of the investors. Further, governments as trustees of these resources must ensure the investment of these resources benefits their publics.

For us, therefore, the normative foundations of contract cannot be the individualism of the Willistonian tradition in which contracts are just because they were reached through the free will of the contracting parties. This individualism ${ }^{8}$ in which any limitations on

\footnotetext{
4 James Boyle, 'Legal Realism and the Social Contract' (1993) 78 Cornell Law Review 371, 377-8.

5 Ibid, 378.

6 Michael Trebilock, The Limits of Freedom of Contract (Cambridge, MA: Harvard University Press, 1993).

7 See Ira Nerken, 'A New Deal for the Protection of Fourteenth Amendment Rights: Challenging the Doctrinal Bases of the Civil Rights Cases and State Action Theory' (1977) 12 Harvard Civil Rights-Civil Liberties Law Review $297,332$.

8 We do not have space to go into a detailed discussion of various types of individualism (e.g., libertarian, contractarian, or utilitarian). For this, see Michel Rosenfeld, 'Contract and Justice: The Relation between Classical Contract Law and Social Contract Theory’ (1984-1985) 70 Iowa Law Review 769.
} 
the pursuit of self-interests such as freely-made contracts is regarded as illegitimate contemplates a social order inconsistent with the modern international human rights movement as well as the vast array of new contractual arrangements in the extractive industry. While modern international human rights norms recognize individual autonomy, unlike the Willistonian tradition they do not assume strict neutrality of the underlying social order. Instead, modern notions of international human rights law inhere in them a vision of an ideal social order in which the rights, not merely of individuals but of groups, are protected-and that protecting one set of rights over another would be an unacceptable trade off.

Conceptualizing contracts merely as products of the will of the parties is to recognize the partiality of this perspective. In other words, to think of contracts merely as the product of the will of the contracting parties is to disembed or abstract contracts from the competing purposes they serve by privileging the autonomy of the contracting parties over other substantive goals. ${ }^{9}$ Like scholarship in the post-Second World War period, we take it for granted that the stakes between the individualism of will theory and advocates of social contracts became a fully-fledged debate between 'conservatives touting freedom of contract, on one side, and liberals advocating policing bargains in the interests of weak parties, on the other'. ${ }^{10}$ We take it as given that to assume the justness of natural resource contracts between resource rich governments and investors outside of any external criteria for validity would be to reify an abstract notion of contractual freedom inconsistent with the duties states have to respect, protect, and fulfil rights under international human rights law. It would also be inconsistent with the promises investors make when they sign extraction contracts that benefits such as tax revenues and foreign exchange earnings would flow to the states and the people from where the resources are extracted. ${ }^{11}$

There is another important reason why recognition of multiparty contracts in international investment law is important in the twenty-first century. The creation of traditional international law is based on the consent of states. However, while state consent continues to be important, new forms of international law have emerged. These new forms of international law question the 'assumption that traditional international law is, by definition, legitimate and new forms must be presumed not to be'. ${ }^{12}$ Newer forms of international law such as those embodied in multiparty stakeholder contracts are recognized by some as a "normatively superior benchmark of thick stakeholder consensus that underlies many of the new forms of cooperation'. ${ }^{13}$

\footnotetext{
9 On this notion of dis-embeddedness, see Duncan Kennedy, 'From the Will Theory to the Theory of Private Autonomy: Lon Fuller's Consideration and Form' (2000) 100 Columbia Law Review 94, 136-8.

10 Ibid, 173.

11 See James Gathii, 'Incorporating the Third Party Beneficiary in Natural Resource Contracts' (2014) 42 Georgia Journal of International and Commercial Law (forthcoming) (Gathii, 'Third Party Beneficiary').

12 Joost Pauwelyn, Ramses A Wessel, and Jan Wouters, 'When Structures Become Shackles: Stagnation and Dynamics in International Lawmaking' (2014) 25 European Journal of International Law 733, 762.

13 Ibid, 762. Thick stakeholder consensus is regarded to have been met where the following criteria have been met. (i) the source, respectability, and authority of the norm creating body, (ii) the transparency, openness, and neutrality in the norm's procedural elaboration, and (iii) the substantive quality, consistency, and overall acceptance (consensus) and objectivity of the norm. Ibid.
} 


\section{Non-Binding Approaches And their Strengths And Limits}

Currently, there are two major approaches aiming to address the extraction of natural resources. ${ }^{14}$ One approach involves voluntary or non-binding codes of conduct. Another approach requires using a variety of home-state and international regulations. The first approach uses voluntary or non-binding codes of conduct. One of the oldest examples was a draft Code of Conduct for Transnational Corporations under the UN Center on Transnational Corporations. ${ }^{15}$ There are numerous examples of such voluntary codes, including multi-stakeholder initiatives such as the Kimberley Transparency Initiative, ${ }^{16}$ the 2002 Extractive Industries Transparency Initiative, ${ }^{17}$ and the Global Compact. ${ }^{18}$ There are also the Guiding Principles endorsed in June 2011 by the UN Human Rights Council that encourage private actors to respect human rights (as opposed to protecting them), require states to protect human rights, and expect both to offer those whose rights have been adversely affected by business activities an opportunity to bring grievances and have their complaints remedied. ${ }^{19}$ There are also industry-specific and companyspecific codes. ${ }^{20}$ Although companies and Western-based or funded civil-society groups have played a central part in crafting some of these codes, local communities that suffer the adverse consequences of extractive-industry activities were not included in those consultations and their involvement in the processes or outcomes set in motion by these non-binding codes is little or none.

The second major approach to addressing resource extraction challenges are a variety of home- or host-state regulations - these are regulatory approaches taken by the states where companies are incorporated or in the states where they operate. ${ }^{21}$ This approach has included using favourable laws to bring suit against extractive companies for violation of human rights, environmental and other laws in their home countries. ${ }^{22}$ For example, Canada enacted

\footnotetext{
14 Here we simplify a rather broad area by emphasizing the distinction between legally-binding and non-legally-binding approaches. The modern trend is to conceive of the field as occupied by multiple options. For example, see Oliver De Schutter, 'The Accountability of Multinationals for Human Rights Violations in European Law', Center for Human Rights and Global Justice Working Papers 1/2004, http://chrgj.org/wp-content/uploads/2012/07/s04deschutter.pdf (accessed 1 August 2015).

15 See United Nations Commission on Transnational Corporations, 'Draft United Nations Code of Conduct on Transnational Corporations', UN Doc E/C.10/1984/S/5 (1984).

16 See Kimberly Process, 'About', http://www.kimberleyprocess.com/en/about (accessed 1 August 2015).

17 See Extractive Industries Transparency Initiative, 'History of EITI', http://eiti.org/eiti/history (accessed 1 August 2015).

18 For example, the UN encourages its vendors to participate in the Global Compact. 'Overview of the UN Global Compact', http://www.unglobalcompact.org/AboutTheGC/index.html (accessed 1 August 2015).

19 Guiding Principles, note 1. For an excellent exposition of the possibilities and limitations of the Guiding Principles, see Surya Deva and David Bilchitz (eds.), Human Rights Obligations of Business: Beyond the Obligation to Respect (Cambridge: Cambridge University Press, 2013).

20 See, e.g., Coca Cola, 'Code of Business Conduct' (August 2012), http://assets.coca-colacompany.com/45/59/ f85d53a84ec597f74c754003450c/COBC_English.pdf (accessed 1 August 2015); Rio Tinto, 'The Way We Work: Our Global Code of Business Conduct' (December 2009), http://procurement.riotinto.com/documents/The_way_we_ work___English___Final.pdf (accessed 1 August 2015); Nestle, 'Code of Business Conduct' (2008), http://www.nestle.com/ asset-library/Documents/Library/Documents/Corporate_Governance/Code_of_Business_Conduct_EN.pdf (accessed 1 August 2015).

21 For a recent criticism of non-binding mechanisms and argument in favour of home-state regulation, see Penelope Simons and Audrey Macklin, The Governance Gap: Extractive Industries, Human Rights and the Home State Advantage (London/New York: Routledge, 2014).

22 See, e.g., Craig Scott (ed.), Torture as Tort: Comparative Perspectives on the Development of Transnational Human Rights Litigation (Oxford: Hart Publishing, 2001).
} 
a code of conduct for its multinational corporations operating in the mining industry and opened an office to monitor and enforce the code. ${ }^{23}$ Another series of home-state regulations sought to enforce contract transparency to address issues of disclosure and confidentiality in extractive industry contracts signed between developing states and investors with the goal of 'promoting responsible management of natural resources for growth and development' ${ }^{24}$ Contract transparency promotes the publication of all signed contracts, the vetting of contracts by parliament, and the public and limited confidentiality provisions to safeguard only commercial secrets. Adherents of contract transparency also argue that transparency is essential because it acts as an incentive for governments and investors to make contracts beneficial to citizens, deter corruption, and aid in government oversight of extractive industries. $^{25}$ Closely related to contract transparency is revenue transparency. Revenue transparency aims at the transparent administration and management of natural resource wealth and revenues with a view to maintaining credibility in the collection and distribution of natural resource revenue and wealth. ${ }^{26}$ For example, the United States (US) has enacted a corporate disclosure law that requires companies to disclose any payments to a foreign government for oil, gas, or mineral resource extraction in countries like the Democratic Republic of Congo in their annual reports. ${ }^{27}$ Some parts of this law were successfully challenged in a federal court. $^{28}$

Clearly, home-state approaches raise very important possibilities in holding companies accountable. They open up legal and policy spaces of contestation of extractive industry activities in the home state of the investor. In this sense, they serve as an important policy and legal lever to make investors and host states more amenable to ensuring natural resources follow prescribed rules that may have been designed to ensure extractive industry operations enure to the benefit of the publics in the countries where these corporations operate. However, home-state solutions are often located far from host states and do not often give citizens adversely impacted the ability to use such mechanisms. Law suits are a unique exception. The US Alien Tort Statute was for about three and a half decades used to challenge violations of human rights where an investor has a connection with the US. However, in 2013 the US Supreme Court largely eviscerated this option by holding that only suits against corporations whose conduct touches and concerns the US could be brought under that statute. ${ }^{29}$

\footnotetext{
23 Government of Canada, Foreign Affairs Trade and Development, 'Doing Business the Canadian Way: A Strategy to Advance Corporate Social Responsibility in Canada's Extractive Sector Abroad' (14 November 2014), http://www. international.gc.ca/trade-agreements-accords-commerciaux/topics-domaines/other-autre/csr-strat-rse.aspx (accessed 1 August 2015). See also Canadian Business Ethics Resource Network, 'Building the Canadian Advantage: Ottawa's Approach to Corporate Social Responsibility' (4 January 2013), http://cbernblog.ca/2013/01/building-the-canadianadvantage-ottawas-approach-to-corporate-social-responsibility/ (accessed 1 August 2015) (describing that Canada released a report that outlined a four-tier approach to ensure that Canadian companies would become the most competitive in international markets based on their ability 'manage social and environmental risks').

24 See Peter Rosenblum and Susan Maples, Contracts Confidential: Ending Secret Deals in the Extractive Industries (New York: Revenue Watch Institute, 2009).

25 Ibid, 16-17.

26 See, e.g., International Monetary Fund, 'Guide on Resource Revenue Transparency' (2007), https://www.imf.org/ external/np/fad/trans/guide.htm (accessed 1 August 2015).

27 Dodd-Frank Wall Street Reform and Consumer Protection Act 2010 (US).

28 National Association of Manufacturers v Securities and Exchange Commission 748 F 3d 359 (DC Cir 2014).

29 Kiobel v Royal Dutch Petroleum Co. 133 S Ct 1659 (2013)
} 
Our premise is that these non-binding and home-based approaches are by themselves insufficient to provide remedies to those who suffer the unfortunate consequences of resource extraction. The contractual options discussed in this article are important supplements to these approaches. The contractual options we discuss in this article, unlike many home-based approaches, are consistent with Principle 9 of the UN Principles for Responsible Contracts which contemplates that businesses should have in place grievance mechanisms for non-contractual parties affected by a project. ${ }^{30} \mathrm{We}$ thus argue in favour of contractual approaches to resolving extractive industries' problems as an important supplement to the available toolkit. For example, the third-party beneficiary principle from the law of contracts has the potential to tilt the incentives for investors and governments to pay more attention to vulnerable communities and peoples in resource extraction scenarios, because contracts - unlike voluntary and non-binding codes-create enforceable obligations at the front end. However, arguing in favour of contractual approaches does not suggest that we agree with the contents of all the contracts that we review in part $\mathrm{V}$. While newer types of agreement make an important turn towards contractualizing responsibilities and in fashioning new accountability regimes, they are only a beginning. For example, many of the contracts we review here could be better drafted to reflect the multiplicity of actors that are affected by natural resource extraction. This is particularly so because the absence of legally-binding regimes for accountability, particularly in the violent extraction of mineral resources, is facilitated by weak states lacking effective control over their territory and by the extremely lucrative trading of natural resources. ${ }^{31}$

\section{Responsibilities of EXtractive Corporations}

In this part of the article, we argue that corporations have responsibilities as moral agents as a prelude to our discussion on the turn to remedial regimes provided by the law of contract.

First, there is a moral and therefore an ethical space in corporate and not just in government decision-making. After all, the decision makers in corporations and governments are individuals and we should not be fooled by the conceptual distinction between artificial and natural persons created by the law to attribute moral or ethical responsibility only to artificial entities to the exclusion of the individuals that stand behind governments and corporations. In addition, in the business context, profits are not the only motivation that managers have. In fact, the most elemental lessons of human behaviour are filled with evidence that human agency is not solely motivated by self-interest. As Amartya Sen has argued, a concept of rationality that closely and almost exclusively argues that individual behaviour is driven primarily by self-interest, is overly narrow since it presupposes that individual preferences can be represented by a one-dimensional scale excluding personal goals motivated by moral standards as well as long-term versus short-term goals. ${ }^{32}$

\footnotetext{
30 Human Rights Council, 'Principles for Responsible Contracts: Integrating the Management of Human Rights Risks into State-Investor Contract Negotiations: Guidance for Negotiators', A/HRC/17/31/Add.3 (25 May 2011). Principle 9 contemplates that business should have in place grievance mechanisms for non-contractual parties affected by a project. 31 James T Gathii, War, Commerce and International Law (Oxford: Oxford University Press, 2010) 216-22, $237-42$.

32 Amartya Sen, Choice, Welfare and Measurement (Oxford: Basil Blackwell, 1983) 82-104, as quoted by Peter Self, Government by the Market? The Politics of Public Choice (London: Macmillan, 1993) 9.
} 
Second, for the most part, corporations and governments hold themselves up as only being bound by positive laws rather than by abstract moral principles. Hence by virtue of their sovereignty, states argue that they are only bound by rules and laws that they have expressly consented to. To the extent that positive law (like international and corporate law) is therefore influenced by ideas of power and interest, this distances ideas of subjectivism and morality from legal norms and rules both domestic and international. ${ }^{33}$ However, to argue that abstract ideas of sovereignty and consent which are hallmarks of positive law are the sole template guiding state and corporate behaviour is to ignore the fact that both the corporate shield and sovereignty are veils behind which the motivations and the conduct of corporations is directly traceable to discrete individuals. More important, however, is the idea that power and interest are not the only motivations of state and corporate behaviour unless we view states as having no space for a set of shared values ${ }^{34}$ of right and wrong, such as human rights.

Third, those who overstate the primacy of positive law strictly divorced from notions of right and wrong, overlook the fact that even in the area of corporate law notions of fairness are part of the innumerable doctrines of equity often invoked by courts to moderate the rough contours of positive law. Examples here are innumerable. They include directorial duties to avoid conflicts of interest that are now legislatively required; duties to ensure fair dealing and not merely fair price in situations where a director is involved in a transaction involving a conflict of interest as well as duties that controlling shareholders in a corporation have to minority shareholders. The point here is simply that notions of fairness are wired into the very fabric of corporate law and governance in most legal systems around the world.

\section{Mapping the Turn to Remedial Regimes Provided by Contract}

Contracts are the life of extractive industry governance. ${ }^{35}$ Most extractive industry contracts involve private corporate actors. The involvement of private actors does not, however, suggest that the contracts are purely private arrangements. In fact, as we have argued above, conceptualizing extractive industry contracts as exclusively private does not adequately reflect their status. Such a narrow view of these contracts has adverse implications for any responsibilities that may be owed to those most adversely impacted by extractive industry operations. ${ }^{36}$ Even though contracts form the core of governance in extractive industry regulation, the ramifications of contracts for corporate liability and responsibility has not been fully explored. ${ }^{37}$ As Tienhaara notes, foreign investment contracts are 'much less studied and poorly understood'. ${ }^{38}$ Some important studies of

\footnotetext{
33 Oscar Schachter, International Law in Theory and Practice (Dordrecht: Nijhoff, 1991) 35-37.

34 See, e.g., Terry Nardin, Law, Morality and the Relations of States (Princeton, NJ: Princeton University Press, 1983) 19. See also Joseph S Nye, The Paradox of American Power: Why the World's Only Superpower Can't Go It Alone (New York: Oxford University Press, 2003).

35 Our focus in this article is on oil, natural gas, and mining.

36 On debunking 'the myth of contract as apolitical', see Natasha A Affolder, 'Rethinking Environmental Contracting' (2010) 21 Journal of Environmental Law and Practice 155, 176.

37 See Lorenzo Cotula and Kyla Tienhaara, 'Reconfiguring Investment Contracts to Promote Sustainable Development' in Karl P Sauvant (ed.), Yearbook on International Investment Law and Policy 2011-2012 (Oxford: Oxford University Press, 2013) 281, 282.

38 Kyla Tienhaara, 'Foreign Investment Contracts in the Oil and Gas Sector: A Survey of Environmentally Relevant Clauses' (2011) 3 Sustainable Development Law and Policy 15.
} 
extractive industry contracts as well as templates and sustainable development perspectives on these contracts have begun to emerge. ${ }^{39}$ However, most of these studies remain largely focused on state-investor contracts. Corporate liability and remedial implications of some of the variety of contracts explored in this article remain seldom studied in these new studies. ${ }^{40}$ This part of the article fills in that gap and in so doing offers a critical assessment of a variety of contracts including state-investor contracts, investor-local community contracts, unilateral deeds and tripartite ${ }^{41}$ arrangements in multiple jurisdictions. ${ }^{42}$

We explore the turn to contracts addressing some of the challenges that have pervaded natural resource extraction. In this part of the article, we proceed in two sections. First we introduce the relevant contracts by theme - economic (investment), environmental, human rights, and social. For many years, investment contracts between states and investors were the sole focus of the extractive industry. These contracts define the rights and obligations of the state and investor parties without much of a robust assessment of the interests of individuals and communities impacted by extractive industry activities. More recently, there have been, in addition to the state-investor contracts, some other extractive industry-related contracts that address environmental, social, and sometimes, human rights issues. These newer types of contracts have begun outlining in new ways expanded responsibilities for all parties involved in extractive industry activities beyond those in classical state-investor contracts. In addition to examining these newer types of contracts closely, we also critically analyse them, especially along the axes of the composition of the parties and the types of responsibilities that they introduce.

\section{A. Extractive Industry Contracts and Responsibility}

In this section, we demonstrate how newer types of extractive industry-related agreements and contracts address core themes namely, economic, environmental, human rights, and social issues. These are precisely the types of issues likely to generate corporate liability in extractive industry operations. First, there are investment contracts which are the major form of contracts in this area. These are typically formed between states, government departments, government-owned/controlled entities such as state oil companies and investors.

\footnotetext{
39 See, e.g., Principles for Responsible Contracts, note 30; Model Mining Development Agreement Project, 'Model Mine Development Agreement' (MMDA) (04 April 2011), http://www.mmdaproject.org/presentations/ MMDA1_0_110404Bookletv3.pdf (accessed 1 August 2015); Lorenzo Cotula, Investment Contracts and Sustainable Development: How to Make Contractors for Fairer and More Sustainable Natural Resource Investments (London: International Institute for Environment and Development, 2010).

40 But see Sunrita Sarkar et al, Mining Community Development Agreements - Practical Experiences and Field Studies (Washington DC: The World Bank, 2010).

41 We use the term 'tripartite' in this article to identify the type of parties involved in a contract rather than the number of the actual parties. While there could be more than three parties, we refer to a contract as a tripartite agreement if it involves three types of parties: governments, investors, and local communities.

42 This is not an exhaustive study for two reasons. First, too many extractive industry contracts exist to offer a comprehensive study in an article of this length. Second, many extractive industry contracts remain confidential (even though access to contracts has improved with some of the initiatives to further transparency) making a comprehensive study of these important instruments difficult. Hence the choice of contracts discussed in this article is influenced by availability in the public domain. Tienhaara, note 38, is a very useful resource for some of the contracts discussed in Part V(B)(1). In spite of the limitations generated by availability of contracts, this article offers a critical review of a wide variety of extractive industry contracts in multiple jurisdictions. On transparency, see generally Rosenblum and Maples, note 24.
} 
Large extractive industry projects have the potential to implicate multiple contracts including contracts among states where the project is multi-jurisdictional. ${ }^{43}$ For example, projects such as the Baku-Tbilisi-Ceyhan pipeline project, Chad-Cameroon Pipeline Project, and the West African Gas Pipeline all involved series of intergovernmental agreements. ${ }^{44}$ Affolder notes that a 'typical large project may involve fifteen or more contracting parties from a number of different contracts, tied together through over forty major contracts'. ${ }^{45}$ Here, we focus on those 'primary contracts' that are 'concerned with exploration or exploitation of the resource' between the government(s) and the investor(s). ${ }^{46}$ Even within primary investment contracts, a wide variety of contracts exist. For example, primary investment contracts in upstream exploration and production of oil and gas vary across projects and include concessions, production sharing contracts, service contracts, and, in some cases, joint ventures typically between a state oil company and foreign companies. ${ }^{47}$

Investment, especially foreign investment, contracts have traditionally not included many significant clauses on responsibility and liability to third parties. This is partly because these contracts have been regarded as instruments that define the rights and responsibilities of the specific parties to the instruments. In our view, there is no reason why investment contracts should be narrowly concerned with merely defining the rights and obligations of states and investors. After all, these investment contracts put in motion operations that impact on the environment in ways that lay the basis for corporate responsibility for environmental damage. ${ }^{48}$ In fact, a study of environmental clauses in foreign investment contracts found references to domestic environmental law, industry standards, international environmental agreements, and 'development of project-specific environmental standards' in different combinations or separately. ${ }^{49}$ We return to these contracts in the next section.

Second, the turn to contracting in environmental law and the potential for natural resource extraction to impact communities and the environment make environmental contracts a necessary part of this analysis. ${ }^{50}$ Although a complete discussion of environmental contracts is beyond the scope of this article, we often reference environmental contracts given that environmental impacts are a major area of responsibility in extractive industry projects. In fact, many of the challenges faced in

\footnotetext{
43 Rosenblum and Maples note that 'a typical oil project could have around 100 contracts supporting and flowing from the project. Most of these contracts are between private parties, such as contractors and sub-contractors, private banks, and individual financiers'. Ibid, 18

44 See, e.g., Agreement among the Azerbaijan Republic, Georgia and the Republic of Turkey relating to the Transportation of Petroleum via the Territories of the Azerbaijan Republic, Georgia and the Republic of Turkey through the Baku-Tbilisi-Ceyhan Main Export Pipeline (18 November 1999).

45 Natasha Affolder, 'Why Study Large Projects? Environmental Regulation's Neglected Frontier' (2011) 44 University of British Columbia Law Review 521, 526.

46 Rosenblum and Maples, note 24, 18. We do not address the myriad of contracts that a company might form with contractors and service providers or for purposes such as sale or transportation of the resources. We also do not discuss government-local community contracts. For examples of these agreements, see Government of British Columbia, 'First Nations Negotiations', http://www2.gov.bc.ca/gov/content/environment/natural-resource-stewardship/consultingwith-first-nations/first-nations-negotiations (accessed 2 August 2015).

47 Yinka Omorogbe, The Oil and Gas Industry: Exploration and Production Contracts (Oxford: Malthouse Press, 1997).

48 See, e.g., Tienhaara, note 38.

49 Ibid, 16.

50 See generally Affolder, note 36 .
} 
natural resource extraction are environmental in nature. ${ }^{51}$ Various forms of environmental contracts have been adopted. Voluntary environmental contracts are sometimes used in the US and in European countries. ${ }^{52}$ Environmental contracts are also formed by several compositions of actors including 'between companies and regulators, companies and community groups, or companies and indigenous peoples' ${ }^{53}$ Of particular interest in this article are those environmental contracts that involve states, investors, and local communities as parties. Canada's mining industry has witnessed the adoption of this form of contract. With regard to Canada's Ekati mine operated by BHP, indigenous communities participated in negotiating the environmental agreement but were not parties; instead they became parties to the Implementation Protocol. ${ }^{54}$ The rationale for the Ekati Mine Environmental Agreement is quite instructive. This Agreement provided for direct involvement of indigenous communities in 'the regulatory process', and in so doing addressed the peoples' 'lack of confidence in the traditional regulator process'. ${ }^{55}$ It set up a 'multi-party negotiation' model and provided a means for addressing indigenous peoples' concerns and 'developing consensus regarding key regulatory requirements'.56

Subsequent to the formation of the Ekati Mine Environmental Agreement, the Federal Government of Canada, a Provincial Government, the mining companies, and indigenous communities participated as parties to two Environmental Agreements formed in relation to the Diavik mine project ${ }^{57}$ and the De Beers Canada Mining Inc. Snap Lake diamond project. ${ }^{58}$ These legally-binding ${ }^{59}$ tripartite (state-investor-localcommunity) agreements create contractual obligations and responsibility that the parties to the contract may enforce through binding arbitration or other forms of dispute settlement as prescribed in the agreements. ${ }^{60}$ The rights acquired under the agreements are no substitute for any other rights or remedies that the parties may have in law, especially by virtue of environmental legislation. Instead, they add to those rights and remedies. ${ }^{61}$ These environmental contracts that directly involve local communities are

\footnotetext{
51 See Rhuks Temitope Ako, Environmental Justice in Developing Countries: Perspectives from Africa and Asia-Pacific (London/New York: Routledge, 2013).

52 See generally Kurt Deketelaere and Eric W Orts (eds.), Environmental Contracts: Comparative Approaches to Regulatory Innovation in the United States and Europe (London: Kluwer Law International, 2001).

53 Affolder, note $36,156$.

54 Canadian Institute of Resources Law, 'Independent Review of the BHP Diamond Mine Process' (30 June 1997), http://www.aadnc-aandc.gc.ca/eng/1100100036028/1100100036030 (accessed 2 August 2015).

55 Ibid, 18.

56 Ibid.

57 'Environmental Agreement between Her Majesty the Queen in Right of Canada and the Government of the Northwest Territories and Diavik Diamond Mines Inc. and Dogrib Treaty 11 Council and Lutsel K'E Dene Band and Yellowknives Dene First Nation and North Slave Metis Alliance and Kitikmeot Inuit Association' (8 March 2000), http://www.emab.ca/Portals/0/Documents/diavik_enviro_agree.pdf (accessed 2 August 2015) (Diavik Environmental Agreement).

58 'Environmental Agreement between Her Majesty the Queen in Right of Canada and the Government of the Northwest Territories and De Beers Canada Mining Inc. and Dogrib Treaty 11 Council and Lutsel K'E Dene Band and Yellowknives Dene First Nation and North Slave Metis Alliance (2004), http://www.slema.ca/wp-content/uploads/ 2011/02/De-Beers-Final-Environmental-Agreement-PDFl.pdf (Snap Lake Environmental Agreement).

59 'Snap Lake Environmental Agreement', ibid, Art 1.1; 'Diavik Environmental Agreement', note 57.

60 'Diavik Environmental Agreement', ibid, Art 16; 'Snap Lake Environmental Agreement', ibid, Art 13.

61 'Snap Lake Environmental Agreement', ibid, Art 14.1; 'Diavik Environmental Agreement', ibid, Art 17.1.
} 
apposite examples of the use of contracts as public tools for regulation and provision of access to remedies for people impacted by extractive projects.

Third, human rights violations have also been a major source of contention. In fact, the contents of (state-investor) investment contracts and other instruments may have significant implications for human rights. ${ }^{62}$ Allegations of corporate complicity in human rights abuses related to the extraction of natural resources arise quite often. ${ }^{63}$ From the experience of the Ogoni with Shell in Nigeria, ${ }^{64}$ the Sudanese people and Talisman Energy in Southern Sudan ${ }^{65}$ to the Mayan Q'eqchi' and Hudbay Minerals in Guatemala, ${ }^{66}$ local communities, civil society groups, states, investors, lenders, and the international community have severally engaged with human rights issues emanating from oil, gas, and mining activities. Other than the ongoing Hudbay Minerals litigation in Canada, these examples of corporate allegations have not yielded legal liability (as determined by foreign courts) for the investors.

A (quasi-) contractual method for addressing human rights issues has emerged in the form of the Human Rights Undertaking utilized by British Petroleum-led Baku-TbilisiCeyhan (BTC) Pipeline Company in the Baku-Tbilisi-Ceyhan project. ${ }^{67}$ By virtue of this document, BTC Company made undertakings regarding human rights, health, safety, and environmental considerations and noted at clause 3(a) that the Undertaking is 'a legal, valid and binding obligation'. ${ }^{68}$ The enforceability of the unilateral deed and the nature of the remedies that it provides have been the subject of debate. ${ }^{69}$ The Undertaking establishes a state-investor relationship with regard to the enforcement of the obligations created through the instrument and provides some acknowledgement of corporate accountability with regard to human rights. However, it is limited because of its nature as a unilateral deed and because of the obligations that BTC Company could have assumed but did not. Nevertheless, the Undertaking demonstrates

\footnotetext{
62 Amnesty International has released some reports on the implications of extractive projects and the contracts that serve as the legal background for these projects. See Amnesty International, Human Rights on the Line: The BakuTbilisi-Ceyhan Pipeline Project (London: Amnesty International, 2003); Amnesty International, Contracting Out of Human Rights: The Chad-Cameroon Pipeline Project (London: Amnesty International, 2005).

63 On corporations and alleged human rights abuses, see generally Report of the Special Representative of the Secretary-General, 'Human Rights and Transnational Corporations and other Business Enterprises (Corporations and Human Rights: A Survey of the Scope and Patterns of Alleged Corporate-Related Human Rights Abuse)', A/HRC/8/5/ Add.2 (23 May 2008).

64 Social and Economic Rights Action Center and the Center for Economic and Social Rights v Federal Republic of Nigeria, African Commission on Human and Peoples' Rights, Communication No 155/96; Wiwa et al v Royal Dutch Petroleum et al, 226 F 3d 88, (2000); Kiobel v Royal Dutch Petroleum Co, note 29.

65 Simons and Macklin, note 21; Presbyterian Church of Sudan v Talisman Energy 583 F 3d 244 (2009).

66 See Choc v Hudbay Minerals Inc. 2013 ONSC 1414. Hudbay Minerals is a Canadian corporation being sued in the courts of its home state.

67 'The Baku-Tbilisi-Ceyhan Pipeline Company, BTC Human Rights Undertaking' (22 September 2003), www. thecornerhouse.org.uk/sites/thecornerhouse.org.uk/files/Human\%20Rights\%20Undertaking.pdf (accessed 2 August 2015).

68 For discussion of the BTC Human Rights Undertaking, see Jernej Lernar Černič, Human Rights Law and Business: Corporate Responsibility for Fundamental Human Rights (Netherlands: Europa Law Publishing, 2010) 241-3.

69 Terra Eve Lawson-Remer, 'A Role for the International Finance Corporation in Integrating Environmental and Human Rights Standards into Core Project Covenants: Case Study of the Baku-Tbilisi-Ceyhan Oil Pipeline Project' in Olivier De Schutter (ed.), Transnational Corporations and Human Rights (Oxford: Hart Publishing, 2006) 393, 416-20 (noting at 419 that 'the Undertaking does not establish the right of locally affected populations to hold the BTC Co accountable for injuries relating to human rights, health, safety or the environment. ... it remains solely up to the host governments to demand redress from BTC Co for any breach of its human rights commitments').
} 
that it is possible to hold corporations accountable for human rights violations through contractual instruments if those instruments provide accordingly.

Fourth, the social dimension of natural resource extraction is also often contentious, creating the need for social impact assessments in some projects. The extractive industry has witnessed a proliferation of social agreements and benefits contracts which oblige investors to undertake projects that directly benefit local communities and that sometimes require investors to minimize the adverse effects of their investment operations in ways consistent with the interests of these communities. These contractual arrangements address mostly social issues and provide benefits to host and impacted communities. They are discussed in detail in the next section of this article.

\section{B. Contemporary Framework for Extractive Industry Contracts}

\section{State-Investor Contracts}

State-investor contracts have dominated extractive industry relationships for decades. During the early to mid-twentieth century, capital importing states granted excessively large concessions to foreign investors to explore for and exploit petroleum resources within their jurisdictions. Sometimes these concessions covered entire territories. In Abu Dhabi, the concession included 'the whole of the lands which belong to the rule of the Ruler of Abu Dhabi and its dependencies and all the islands and the sea waters which belong to that area' ${ }^{70}$ Qatar also formed a similar agreement that granted to the investors 'the sole right throughout the Principality of Qatar to explore, to prospect, to drill for and to extract and to ship and to export, and the right to refine and sell petroleum and natural gases, ozokerite, asphalt, and everything which is extracted therefrom'. ${ }^{71}$ These agreements were regarded as beneficial to these states and were termed 'economic development agreements'. ${ }^{72}$ During the decolonization era of the 1960s and 1970s, the Third World countries, some of which had adopted these concessions, sought to redefine international economic law through several mechanisms, including through the United Nations General Assembly and the passing of the Declaration on the Establishment of a New International Economic Order ${ }^{73}$ and the Charter of Economic Rights and Duties of States. ${ }^{74}$ At about this time, there was also a series of nationalizations of the properties of foreign investors, prominent among which was the Libya nationalization. ${ }^{75}$ Subsequent to these events, investment treaties proliferated, ensuring that the property and investments of foreign investors were protected. ${ }^{76}$ While investment treaties ensured

\footnotetext{
70 See Art 2(a) of the Agreement of 11 January 1939 between the Sheikh of Abu Dhabi and Petroleum Development (Trucial Coast) Limited, cited in Petroleum Development (Trucial Coast) Ltd. v Sheikh of Abu Dhabi (1951) 18 ILR 144, 147.

71 See Petroleum Development (Qatar) Ltd. v Ruler of Qatar (1951) 18 ILR 161. These agreements often excluded religious sites, cemeteries, and other similar lands.

72 James N Hyde, 'Economic Development Agreements' (1962) 105 Recueil des cours 271; Christopher T Curtis, 'The Legal Security of Economic Development Agreements' (1988) 29 Harvard International Law Journal 317.

73 UN General Assembly, 'Declaration on the Establishment of a New International Economic Order', A/RES/S-6/ 3201 (1 May 1974).

74 UN General Assembly, 'Charter of Economic Rights and Duties of States', A/RES/29/3281 (12 December 1974)

75 See Texaco Overseas Oil Petroleum Co. v Libyan Arab Republic (1979) 53 ILR 389.

76 See generally Rudolf Dolzer and Christoph Schreuer, Principles of International Investment Law (Oxford: Oxford University Press, 2012).
} 
additional protection for foreign investors, state-investor contracts in the extractive industries continued. The internationalization of investment protection was however not met with similar internationalization of the protection of individuals and communities affected by the development of natural resources. Instead soft norms emerged in this area and there was a turn to contractual responsibility, which we map in this article.

There are several types of state-investor contracts. ${ }^{77}$ From production sharing contracts (PSCs), joint venture agreements, to transnational agreements such the West African Gas Pipeline Project International Project Agreement (WAGP IPA), ${ }^{78}$ the scope of relevant agreements is very large and we do not purport to offer comprehensive analyses of the provisions of the agreements. Instead we specifically refer to provisions that in our view lay the basis for corporate liability for harms to individuals and communities. In this task we rely on actual agreements as well as available Model Agreements. ${ }^{79}$ In addition to the well-known types of state-investor contracts (primary investment contracts), governments and investors may form socioeconomic agreements that are similar to Community Development Agreements formed with local communities. $^{80}$ These socioeconomic agreements focus on social responsibility. One of the many contracts related to BHP's diamond project in Canada's Northwest Territories is a Socioeconomic Agreement between the Government of the Northwest Territories and BHP Diamonds Inc. ${ }^{81}$ This Socioeconomic Agreement establishes frameworks to ensure that the diamond project benefits the communities, accounts for 'the social, economic and cultural well-being' of the communities and addresses the impacts of the project. ${ }^{82}$ Also in Greenland, Impact Benefit Agreements are formed between licensees, municipalities, and national governments. ${ }^{83}$ These Impact Benefit Agreements are formed, in part, in order to mitigate negative economic and social impacts and to promote positive impacts including health, social, and cultural well-being and employment. ${ }^{84}$

PSCs have been a major feature of state-investor oil and gas contracts in parts of the world for some time. Many of the earlier PSCs focused on fiscal and technical

\footnotetext{
77 In this section, we only focus on the major agreements between states and investors, that is, the agreements that grant the rights to develop extractive resources.

78 'West African Gas Pipeline Project International Project Agreement between the Republic of Benin, the Republic of Ghana, the Federal Republic of Nigeria, the Republic of Togo and the West African Gas Pipeline Company Limited' (22 May 2003) (WAGP IPA).

79 Model Agreements could be significantly modified through the negotiation process for a contract. Nevertheless, these models offer an opportunity to assess some of the prevailing terms in state-investor contracts.

80 For Community Development Agreements, see the discussion in Part V (B)(2) of this article.

81 See 'Socio-Economic Agreement: BHP Diamonds Project between Government of the Northwest Territories (Canada) and BHP Diamonds Inc.' (22 October 1996), http://www.miningnorth.com/wp-content/uploads/2011/10/ EKATI-Socio-Economic-Agreement.pdf (BHP Socio-Economic Agreement 1996).

82 Ibid, para. G.

83 See 'Impact Benefit Agreement under Mineral Exploitation Licence 2014/21 between the Licensee under the Exploration Licence as represented by True North Gems Greenland A/S and Municipality of Kimmuneqarfik Sermersooq and Greenland Government' (June 2014), http://naalakkersuisut.gl/ /media/Nanoq/Files/Publications/ Raastof/ENG/Signed\%20IBA\%20TNG\%20ENG\%2016\%2006.pdf (Greenland: True North IBA 2014); 'Impact Benefit Agreement under Licences 2008/11, 2002/15, 2005/16 and 2011/16 for 2011 between the Licensee under the Licence as represented by Capricorn Greenland Exploration 1 Limited and Municipality of Qaasultsup, Municipality of Qeqqata, Municipality of Sermersooq and Government of Greenland' (June 2011), http://www.qaasuitsup.gl/ /media/ Files/Erhverv/Olie-og-mineraler/IBA-aftaler/IBA-Cairn-2011.ashx (accessed 2 August 2015).

84 'Greenland: True North IBA 2014', ibid, cl 2.1.4(1).
} 
requirements of petroleum operations. ${ }^{85}$ These PSCs defined the rights and obligations of the state and investor with a focus on the financial and technical obligations owed by the investor to the state as well as the rights that the investor acquired. ${ }^{86}$ Few obligations were directed towards responsibility for corporate actions that affected individuals and communities. $^{87}$

More recent state-investor contracts appear to be more detailed with regard to provisions that affect the public. ${ }^{88}$ Ghana's Petroleum Agreement with Tullow, Sabre, and Kosmos dedicates Article 17 to environmental protection and safety. ${ }^{89}$ One of Liberia's PSCs also includes requirements for public hearing and public consultations for Environmental and Social Impact Assessments. ${ }^{90}$ Although India's Model Production Sharing Contract 2009 adopts sometimes loose language like being 'mindful' of India's rights and interests in conducting petroleum operations, ${ }^{91}$ it offers even more comprehensive provisions on the environment ${ }^{92}$ including a clause that requires the contractor to 'take necessary and adequate steps to ensure adequate compensation for injury to persons or damage to property caused by the effect of Petroleum Operations'. ${ }^{93}$ Compensation provisions related to injury or property damage are included in a number of state-investor contracts including Uganda's 1999 Model Production Sharing Contract ${ }^{94}$ and Mozambique's 2006 Model Concession Contract. ${ }^{95}$

85 See 'Production Sharing Contract dated 12 June 1973 between Nigerian National Oil Corporation and Ashland Oil (Nigeria) Company' Basic Oil Laws and Concession Contracts (New York: Barrows Co, 1979) ('Nigeria-Ashland PSA 1973'). See also 'Production Sharing Contract between Perusahaan Pertambangan Minyak Dan Gas Bumi Negara (PERTAMINA) and Apex (Bengara-II) Ltd.' (4 December 1997).

86 Other agreements further define the financial incentives and other financial aspects of state-investor relationships. See, e.g., 'Memorandum of Understanding Dated 17 January 1986 between Ashland Oil and Nigeria on Incentives for Enhancing Crude Oil Exports and Encouraging Investments in Exploration and Development Activities' Basic Oil Laws and Concession Contracts (New York: Barrows Co, 1990).

87 For some of the clauses in the earlier PSCs that include some relevant provisions, see 'Nigeria-Ashland PSA 1973', note 85, cl 5(i)(c)/(h)/(j) and cl 6(xii), 12. See also '1988 Operating Agreement between Nigerian National Petroleum Corporation and Topcon Company (Texaco Overseas)' Basic Oil Laws and Concession Contracts (New York: Barrows Co, 1993), cl 6.1.2 and cl 15.1. The relevant earlier clauses were also often framed in general terms that could be difficult to adopt as grounds for legal liability for non-performance and Nigeria's model PSCs in the early 1990s were not very different. See 'Production Sharing Contract of March 1991 between Government Agency and International Companies (Nigeria)' Basic Oil Laws and Concession Contracts (New York: Barrows Co, 1991). See also 'Model Convention of Establishment 1990 (Cameroon)' Basic Oil Laws and Concession Contracts (New York: Barrows Co, 1992).

88 See Article 25 of the 'Model Production Sharing Agreement between the Government of the United Republic of Tanzania and Tanzania Petroleum Development Corporation and ___' (2013) which spans four pages and makes specific references to particular statutes and standards.

89 'Petroleum Agreement among Government of the Republic of Ghana, Ghana National Petroleum Corporation and Tullow Ghana Limited, Sabre Oil and Gas Limited, Kosmos Energy Ghana HC in Respect of the Deepwater Tano Contract Area' (10 March 2006).

90 'Restated and Amended Production Sharing Contract between the Republic of Liberia by and through National Oil Company of Liberia and ExxonMobil Exploration and Production Liberia Limited and Canadian Overseas Petroleum (Bermuda) Limited, Liberia, Offshore Block 13' (8 March, 2013) Art 6.

91 'Model Production Sharing Contract, Eighth Offer of Blocks, Ministry of Petroleum and Natural Gas - Government of India, 2009' Art 8.3(k) (India, Model PSC 2009).

92 Ibid, Art 14.

93 Ibid, Art 14.1(b)(ii). Kenya's Model PSC also includes a provision regarding 'reasonable compensation' for losses suffered. See 'Republic of Kenya, Production Sharing Contract between the Government of the Republic of Kenya and Relating to Block , , sec 9(2).

94 'Uganda: Model Production Sharing Agreement of August 1999 for Petroleum Exploration, Development and Production in Uganda', Art 22.5 (Uganda, Model PSA 1999).

95 'Exploration and Production Concession Contract between the Government of the Republic of Mozambique and for Mozambique Block' (2006), Art 28.3(a) (Mozambique Model Concession Contract 2006). 
As discussed below, the extent to which individuals or communities may enforce such compensation provisions might be determined under contract rules relating to privity in jurisdictions where privity and third party beneficiary rules apply. A 2008 PSC formed with the Kurdistan Regional Government of Iraq provides that, subject to provisions of the contract, the investor is 'liable to third parties to the extent provided under applicable Law for any losses and damage it may cause to them in conducting the Petroleum Operations'. 96 Provisions regarding corporate liability to third parties for losses or damages, especially from environmental pollution, are included in several state-investor contracts. $^{97}$

Brazil's Model Concession Agreement of 2008 specifically requires the concessionaire's operations not to 'cause any damages or losses which might affect other economic or cultural activities in the Concession Area, such as agriculture, cattle breeding, forest industry, gathering, mining, archaeological, biological and oceanographic research, as well as tourism, or which might disturb the well-being of native communities and rural and urban settlements'. ${ }^{98}$ The Concessionaire also assumes 'full and objective responsibility' for damage and loss to the environment and third parties. ${ }^{99}$ Remarkably, Brazil's Model Concession Agreement also includes payments for 'landowner use' in the contract creating a contractual obligation for such payment. ${ }^{100}$ This payment to landowners amounts to one per cent of oil and gas production. ${ }^{101}$ Payments to host communities are often included in community development agreements which are discussed in the next section of this article but in the case of Brazil, they are included as part of the model state-investor contracts. Some newer investor-state contracts in countries like Ghana also include specific provisions regarding social investment in communities. ${ }^{102}$

The absence of, or the contents of, any included social, environmental, or other similar provisions in state-investor extractive industry contracts are not the only concerns that

\footnotetext{
96 'Production Sharing Contract for Taq Taq and Kewa Chirmila Areas in the Kurdistan Region between the Kurdistan Regional Government of Iraq and Genel Energy International Limited and Addax Petroleum International Limited' (26 February 2008), Art 35.1. Article 16.8 also provides that ' $[\mathrm{t}]$ he Contractor shall be responsible for any loss or damage caused to third parties by its or its Subcontractors' personnel solely and directly resulting from their negligence, errors or omissions in accordance with applicable Kurdistan Region Law'. See also Article 17 regarding compensation for occupation and use of land.

97 See 'Agreement on the Joint Development and Production Sharing for the Azeri and Chirag Fields and the Deep Water Portion of the Gunashli Field in the Azerbaijan Sector of the Caspian Sea among the State Oil Company of the Azerbaijan Republic and Amoco Caspian Sea Petroleum Limited, BP Exploration (Caspian Sea) Limited and others' (20 September 1994) Art 26.5 (noting that the 'Contractor shall be liable for those direct losses or damages incurred by a Third Party (other than the Government) arising out of any environmental pollution determined by the appropriate court of the Azerbaijan Republic to have been caused by the fault of the Contractor'). See also 'Model Production Sharing Contract Bangladesh (2008)', Art 10.21.

98 'Concession Agreement for the Exploration, Development and Production of Oil and Natural Gas by and between Agencia Nacional Do Petroleo, Gas Natural E Biocombustiveis - ANP and Concession 2008].

99 Ibid, Art 21.5.

100 Ibid, Art 23.1.

101 Ibid, Annex V(d) (noting that the Concessionaire will pay 'to the landowners of equivalent participation to $1 \%$ (one percent) of the Oil and Natural Gas Production, in accordance with the applicable Brazilian legislation'.

102 Cotula reports that a Stability Agreement (2003) between the Government of Ghana and AngloGold Ltd. provides that the investor would establish community trusts for the mines and contribute one percent of profits to work in the communities. The Production Sharing Agreement (1997) for the Kashagan oil field in Kazakhstan 'requires the consortium to pay 1 per cent of the annual oil development expenditures of US $\$ 5$ million (whichever is greater) to fund social and infrastructure projects proposed by local governments.' Cotula, note 39, 6.4, para. 61 .
} 
some of these agreements raise. Proper negotiation and drafting of the financial provisions in state-investor contracts are essential, as demonstrated by the pre-2008 Mining Development Agreements in Zambia. ${ }^{103}$ These unequal agreements prompted a civil society outcry that led to legislative annulment of these contracts. ${ }^{104}$

State-investor contracts have not typically served as a primary source of contractual responsibility that individuals and local communities can rely on. However, they sometimes include rights and benefits that other parties to the contract or third party beneficiaries like local communities may be able to enforce. ${ }^{105}$ While some of the rights that these contracts create may already exist in other areas of the law, the contracts create an avenue for enforceable contractual obligations. However, depending on applicable law, some state-investor contracts may also exclude the enforceability of rights provided to third party beneficiaries. The WAGP IPA provides an example. ${ }^{106}$ Similar to some of the provisions that have been analysed in this section, clause 20.3 of a version of the WAGP IPA provides that the West African Gas Pipeline Company 'shall pay to any affected legitimate land owners or lawful occupiers of land ... fair compensation for disturbance or damage caused by the activities of the Company or the Project Contractors on such land'. However, the same WAGP IPA excludes non-parties' ability to enforce the terms of the agreement. ${ }^{107}$

As demonstrated in the WAGP IPA example, the extent to which the third party beneficiary rule is applicable to third party enforcement of a state-investor contract depends on the applicable law; in some jurisdictions, the privity issue might not arise at all. However, even if the privity hurdle is surmounted (in situations where privity rules could apply), there might be no awareness of an existing right within a state-investor contract because of the confidential nature of many of these agreements. In addition to the transparency initiatives being adopted, contracts could specifically respond to the confidentiality challenge and provide that the text of the agreement will be published. ${ }^{108}$

\section{Investor-Local Community Contracts}

Investor-local community contracts have acquired an important place in defining relationships related to natural resource development and to regulating these relationships

\footnotetext{
103 'The Government of the Republic of Zambia and Mopani Copper Mines Plc: Mufulira Mine, Smelter and Refinery and Nkana Mines, Concentrator and Cobalt Plant Development Agreement' (31 March 2000); 'The Government of Zambia and Konkola Copper Mines Plc: Amended and Restated Development Agreement' (2000).

104 The Mines and Minerals Development Act 2008 (Zambia), sec 160(1). See John Lungu, 'Copper Mining Agreements in Zambia: Renegotiation or Law Reform?' (2008) 11 Review of African Political Economy 403; Anthony Simpasa et al, 'Capturing Mineral Revenues in Zambia: Past Trends and Future Prospects', Discussion Paper (August 2013), http://www.un.org/en/land-natural-resources-conflict/pdfs/capturing-mineral-revenues-zambia.pdf (accessed 2 August 2015).

105 See Gathii, 'Third Party Beneficiary', note 11; Ibironke T Odumosu-Ayanu, 'Governments, Investors and Local Communities: Analysis of a Multi-Actor Investment Agreement Framework' (2014) 15 Melbourne Journal of International Law 473, 496-7.

106 'WAGP IPA', note 78.

107 Ibid, clause 51, noting that '[a] person who is not a party to this Agreement shall have no right under the Contract (Rights of Third Parties) Act 1999 to enforce any of its terms'.

108 See Brazil Model Concession 2008, note 98, Art 35.4 (noting that ' $[\mathrm{t}]$ he ANP shall publish the full text or summary of the terms of this Agreement in the Federal Official Gazette for purposes of its validity erga omnes'. See also 'Concession Agreement for the Exploration, Development and Production of Oil and Natural Gas by and between Agencia Nacional Do Petroleo and ' (2001) Art 35.4.
} 
and the resource development activities of the relevant actors. Many of these investor-local community contracts are Community Development Agreements (CDAs). As the authors of a Report of the International Institute for Sustainable Development note, '[t]here is a very strong current interest in Impact Benefit Agreements or Community Development Agreements between mining companies and communities'. ${ }^{109}$

CDAs are known by different terminologies around the world. ${ }^{110}$ In some countries, CDAs between investors and local communities are required by statute. ${ }^{11}$ Among the countries that use them, albeit in various formats, are Australia, ${ }^{112}$ Canada, ${ }^{113}$ Ghana, ${ }^{114}$ Greenland, ${ }^{115}$ Nigeria, ${ }^{116}$ and Papua New Guinea. ${ }^{117}$ Compared to countries like Ghana and Nigeria, Australia and Canada have a longer tradition of concluding CDAs in extractive industry projects. ${ }^{118}$ In Canada, these agreements-which are known by different terminologies including Impact and Benefit Agreements (IBAs) ${ }^{119}$ - flow from the sui generis relationship between Indigenous Peoples in Canada and the Canadian Crown. ${ }^{120}$ CDAs are mostly social investment agreements. Commentators note that CDAs are formed where some factors are present, ${ }^{121}$ for example, where there is a government requirement for CDA formation, $^{122}$ in some instances where indigenous lands are involved in resource

109 Howard Mann et al, IISD Report: Model Mining Development Agreement - Transparency Template (Winnipeg: The International Institute for Sustainable Development, 2012) 3.

110 Most CDAs are formed between investors and local communities but some CDAs also involve government actors.

111 For an example of CDAs required by statute, see Minerals and Mining Act 2007 (Nigeria), secs 116 and117; Mines and Minerals Act 2009 (Sierra Leone) secs 139-41; Mining Act 2012 (South Sudan).

112 See, e.g., 'Argyle Diamond Mine Participation Agreement: Management Plan Agreement between Argyle Diamonds Limited and Argyle Diamond Pty. Limited and Traditional Owners' (1 January 2004) ('Argyle Diamond Mine Participation Agreement').

113 See the discussion and the accompanying text in notes $145-53$ of this article.

114 Newmont, a transnational mining company, concluded a series of agreements with the Chiefs and people of the Ahafo Mine Local Community in Ghana. See 'The Ahafo Social Responsibility Agreement between the Ahafo Mine Local Community and Newmont Ghana Gold Ltd.' (29 May 2008) ('Social Responsibility Agreement'); 'Agreement between Newmont Ahafo Development Foundation and Newmont Ghana Gold Ltd.' (29 May 2008) ('Ahafo Development Foundation Agreement'); 'Agreement between Newmont Ghana Gold Ltd. and the Ahafo Mine Local Community on Local Employment' (29 May 2008) ('Ahafo Local Employment Agreement'). For a discussion of CDAs in Ghana, see Ibironke T Odumosu-Ayanu, 'Foreign Direct Investment Catalysts in West Africa: Interactions with Local Content Law and Industry-Community Agreements' (2012) 35 North Carolina Central Law Review 65, 80-87.

115 See note 83 and the accompanying text.

116 For a discussion of CDAs known in Nigeria's oil and gas industry as the Global Memorandum of Understanding, see Odumosu-Ayanu, note 105.

117 Papua New Guinea CDAs include CDAs related to liquefied natural gas as well as solid minerals. PNG Mineral Resources Authority, 'Tolukuma Mining Project MOA Review', http://www.mra.gov.pg/Home/tabid/217/ctl/ViewItem/ mid/881/ItemId/63/Default.aspx?SkinSrc=/Portals/_default/Skins/ExactBusiness/Green-Gray\&ContainerSrc=/Portals/ _default/Containers/DarkKnight/PageTitle_Blue (accessed 2 August 2015).

118 See Ciaran O'Faircheallaigh, 'Understanding Corporate-Aboriginal Agreements on Mineral Development: A Conceptual Framework' in Ciaran O'Faircheallaigh and Saleem Ali (eds.), Earth Matters: Indigenous Peoples, the Extractive Industries and Corporate Social Responsibility (Sheffield: Greenleaf Publishing Ltd., 2008) 67.

119 Janet Keeping, 'Thinking about Benefits Agreements: An Analytical Framework', Canadian Arctic Resources Committee Northern Minerals Program Working Paper No 4, http://www.carc.org/pdfs/NMPWorkingPaper4Keeping.pdf (accessed 2 August 2015).

120 See Odumosu-Ayanu, note 105, 480.

121 David Brereton, John Owen, and Julie Kim, 'Good Practice Note: Community Development Agreements', Centre for Social Responsibility in Mining (26 September 2011) 4, https://www.csrm.uq.edu.au/Portals/0/docs/CSRM-CDAreport.pdf (accessed 2 August 2015).

122 Minerals and Mining Act 2007 (Nigeria). 
extraction, ${ }^{123}$ or to resolve disputes between local communities and investors. ${ }^{124}$ With regard to the resolution of disputes between investors and local communities, it is acknowledged by investors such as Chevron that CDAs are formed in Nigeria's Niger Delta in order to address industry-local community conflicts. ${ }^{125}$ CDAs are essentially, in part, an avenue for industry to acquire a social licence to operate in communities. ${ }^{126}$

CDAs are also relevant in multi-jurisdictional projects. Cotula notes that '14 Memoranda of Understanding were concluded between the West African Gas Pipeline Company and communities impacted by the project in Benin, Ghana, Nigeria and Togo' ${ }^{127}$ Cotula's description of these Memoranda suggests that they are typical CDAs because they 'involve social investment programmes in the areas of education, health, water and sanitation, income generation and capacity building'. ${ }^{128}$

The contents of CDAs vary across locations and may be determined by legislation ${ }^{129}$ or Land Claim Agreements. ${ }^{130}$ The Ahafo mine's host communities in Ghana's arrangement with Newmont provides an example of CDAs in the African context. The Ahafo/Newmont CDAs were negotiated over a period of over two years. ${ }^{131}$ At the end of the negotiation period, three agreements were formed with the chiefs and peoples of the ten communities that are 'physically located' ${ }^{132}$ on Newmont's Mining Lease: the Ahafo Social Responsibility Agreement, the Ahafo Development Foundation Agreement, and the Ahafo Mine Local Community Local Employment Agreement. ${ }^{133}$ Newmont also established the Social Responsibility Forum in $2006^{134}$ and created the Newmont Ahafo Development Foundation 'to support local community development projects in the 10 communities near the mine'. ${ }^{135}$ These agreements together determine some of Newmont's legal responsibilities to these communities.

By the Ahafo Social Responsibility Agreement, which provides for establishment of the Newmont Ahafo Development Foundation, ${ }^{136}$ Newmont commits to "sustainable

\footnotetext{
123 The Canadian IBAs discussed in this section are related to development on indigenous lands.

124 See Brereton, Owen, and Kim, note 121, 65.

125 Chevron notes that the purpose of its CDAs (known as Global Memorandum of Understanding in Nigeria's oil and gas industry) 'is to bring peace and stability to areas where Chevron operates'. Chevron, 'Nigeria: In the Community' (May 2014), http://www.chevron.com/countries/nigeria/inthecommunity/ (accessed 2 August 2015).

126 See Katherine Trebeck, 'Corporate Social Responsibility and Democratisation: Opportunities and Obstacles' in O'Faircheallaigh and Ali (eds.), note 118, 12-13.

127 Cotula, note 39 , box 2 .

128 Ibid.

129 See Minerals and Mining Act 2007 (Nigeria), sec 116(3). According to this provision, CDAs are to include issues such as employment, apprenticeship, training, scholarships, and financial support for the development and maintenance of infrastructure including roads.

130 See 'Agreement between the Inuit of the Nunavut Settlement Area and Her Majesty the Queen in Right of Canada' (25 May 1993) sec 26 and schedule 26-1. Schedule 26-1 provides a list of 'matters considered appropriate for Inuit benefits' including training, preferential hiring, scholarships, business opportunities, housing, safety, health, and hygiene. In addition, schedule 26-1 includes arbitration on this list of matters considered appropriate for Inuit benefits. 131 See Newmont Ahafo Development Foundation '2009 Annual Report: Creating Sustainable Futures through Partnerships' (2009) 4, http://www.nadef.org/downloads/2/228.pdf (accessed 2 August 2015).

132 'Social Responsibility Agreement', note 114, sch 1, sec 1.

133 Ibid.

134 Newmont, 'Community', http://www.newmont.com/operations-and-projects/africa/ahafo-ghana/community/ default.aspx (accessed 2 August 2015).

135 Ibid.

136 Ibid, sec 22.
} 
economic and social development of the Community' and the community commits to 'discussions and consultations with the company' as well as the promotion of 'peace and harmony between itself and the Company'. ${ }^{137}$ Curiously, section 4.2 of the Social Responsibility Agreement states that:

The parties further agree, acknowledge and confirm that this document does not create any legally enforceable rights to the benefit of either of the parties and that all disputes or grievances of any kind arising out of or related to this document or the policies described herein, shall be settled through mediation and conciliation making use of the Dispute Resolution Committee provided for in this Agreement. The Parties hereby renounce their rights to enter into any form of litigation or arbitration on any disputes or grievances arising out this Agreement. ${ }^{138}$

One of the two other Newmont-Ahafo agreements adopts a similar but not identical approach. The Ahafo Mine Local Community Local Employment Agreement, which outlines Newmont's employment policies for the mine, ${ }^{139}$ states emphatically that the document was 'prepared solely to record the mutual understandings reached after extended negotiations'. ${ }^{140}$ In addition, section 1.2 of the Local Employment Agreement notes that the parties 'agree, acknowledge and confirm that all disputes or grievances of any kind arising out of or related to this document or the policies described therein, shall be settled through mediation and conciliation making use of the Dispute Resolution Committee provided for in the Agreement reached between the Company and the Community'. Section 1.2 continues that '[t]he Parties therefore renounce their rights to enter into any form of litigation or arbitration on any disputes or grievance arising out of this Agreement'.

However, the Newmont Ahafo Development Foundation Agreement, by which Newmont commits inter alia to pay one US dollar 'for every ounce of gold' it sells 'in its operations under the Ahafo Mining Lease', ${ }^{141}$ states that Ghanaian law governs the Agreement and disputes may be settled under the Arbitration Act of Ghana. ${ }^{142}$

The explicit exclusion of arbitration and litigation does not mean that parties do not owe legal obligations. Such ouster clauses have been invalidated by courts in exercising their supervisory jurisdiction on the basis of criteria such as the public interest. However, many CDAs do not directly exclude legally-enforceable rights. In fact, these investorlocal community agreements are indeed contracts. ${ }^{143}$ Similar analyses of environmental agreements have been undertaken where these agreements are regarded as contracts irrespective of their views on litigation and arbitration or their designation as binding or non-binding. ${ }^{144}$

137 Ibid, sec 2.

138 Ibid, sec 4.2. Section 23 provides for 'Conflict Resolution Management'.

139 'Ahafo Local Employment Agreement', note 114, sec 1.1.

140 Ibid, sec 1.1 .

141 'Ahafo Development Foundation Agreement', note 114, sec 11.1(i).

142 Ibid, sections 21.1 and 21.2.

143 See Pauwelyn, Wessel, and Wouters, note 12, arguing that informal international law-making promotes accountability mechanisms and accountability-promoting measures beyond classical accountability mechanisms such as litigation.

144 Natasha Affolder, 'Transnational Conservation Contracts' (2012) 25 Leiden Journal of International Law 443, 444 argues that: The choice of describing transnational conservation agreements as "contracts" is a deliberate one. 
The contractual nature of Canadian IBAs is not disputed. These IBAs are mostly 'privately negotiated agreements' formed mostly between investors and communities. ${ }^{145}$ Some IBAs, however, involve governments. ${ }^{146}$ Canadian IBAs may be formed under existing regulatory regimes or based on the initiatives of investors. The contents of IBAs vary but some common provisions remain, including the creation of implementation committees, ${ }^{147}$ financial payments, ${ }^{148}$ employment, ${ }^{149}$ business opportunities, ${ }^{150}$ and training and education. ${ }^{151}$ Some of the IBAs also include provisions relating to the environment, including wildlife conservation and monitoring, mitigation, and compensation for environmental damage. ${ }^{152}$ Most of the IBAs include dispute settlement provisions, mostly in the form of tiered dispute settlement. Often the parties' initial point of recourse is consultation or informal dispute settlement through the Implementation Committee or other committee created under the Agreement, followed by mediation, conciliation, arbitration, and possibly litigation. ${ }^{153}$ Some of these agreements provide specific dispute settlement options for environmental disputes. In this regard, the Raglan Agreement provides that disputes regarding environmental assessment and mitigation measures may be referred to binding arbitration. $^{154}$

Australia's CDAs are not very different. In its articulation of eight management plans, the Argyle Diamond Mine Participation Agreement addresses issues such as the protection of aboriginal sites, training and employment, land access and land

\section{(F'note continued)}

These agreements vary significantly. Some are legally binding; others are not. Many examples might more appropriately be described as ledges, or restrictive covenant, or commitments, or some more amorphously as "voluntary agreements" or "hybrid agreements". But speaking the language of contracting encourages a legal analysis of these agreements, which might otherwise not take place.... One of the consequences of the fact that conservation contracts largely escape the scrutiny of lawyers is that their legality is rarely investigated. Talking about these agreements as "contracts" invites a closer look at the text of these agreements and their legality'.

145 Ken J Caine and Naomi Krogman, 'Powerful or Just Plain Power-Full? A Power Analysis of Impact and Benefit Agreements in Canada's North' (2010) 23 Organization \& Environment 76, 77.

146 See, e.g., 'Inuit Impact and Benefit Agreement for National Wildlife Areas and Migratory Bird Sanctuaries in the Nunavut Settlement Area between the Inuit of the Nunavut Settlement Area and Her Majesty the Queen in Right of Canada', http://www.qia.ca/sites/default/files/files/Publications/IIBA-NWA-MBS-NSA-Final-ENG.pdf (accessed 2 August 2015).

147 'Inuit Impact and Benefit Agreement between Qikiqtani Inuit Association and Baffinland Iron Mines Corporation', secs 2.5 and 4.4.1 creating a 'Senior Executive Committee' and a 'Management Committee' qia.ca/sites/default/files/files/ Publications/qia_-_baffinland_-_iiba.pdf (accessed 2 August 2015) ('Mary River IIBA'); 'Collaboration Agreement between the Northern Village of Pinehouse and Kineepik Metis Local Inc. and Cameco Corporation and Areva Resources Canada Inc.' (12 December, 2012) sec 4.1(a)/(c) creating a 'Joint Implementation Committee', http://www.pinehouselake. ca/images/pdf/Collaboration\%20Agreement.pdf (accessed 2 August 2015) ('Pinehouse Agreement').

148 See, e.g., 'Mary River IIBA', ibid, secs 4.3.2, 4.5.2, and 5; 'Pinehouse Agreement', ibid, sec 4.1(f) and schs C5, 6 and 7.

149 See, e.g., 'Mary River IIBA', ibid, sections 7.3.1, 7.14, 7.12.1-2, and 7.12.4; 'Pinehouse Agreement', ibid, $\sec \mathrm{D} 10$.

150 See, e.g., 'Mary River IIBA', ibid, sec 6; 'Pinehouse Agreement', ibid, sec E4.

151 See, e.g., 'Mary River IIBA', ibid, secs 8.1.3, 8.1.5, 8.4.5, 8.6.1, 8.7.2, and 8.8.1; 'Pinehouse Agreement', ibid, secs D7, D9, and F9.

152 See, e.g., 'Mary River IIBA', ibid, secs 15.2, 17.2.3, and 17.5-17.6.

153 See the dispute settlement clauses of the 'Mary River IIBAs', ibid.

154 'The Draft Raglan Agreement entered into between Makivik Corporation, Qarqalik Landholding Corporation of Salluit, Northern Village Corporation of Salluit, Nunatulik Landholding Corporation of Kangiqsujuaq, Northern Village Corporation of Kangiqsujuaq and Societe Miniere Raglan du Quebec Ltee, to which intervened Falconbridge Limited' (25 January 1995) sec 9.3, http://pubs.aina.ucalgary.ca/makivik/ci236.pdf (accessed 2 August 2015). 
management, cross-cultural training, and decommissioning plans. ${ }^{155}$ Clause 8 of the Agreement outlines the applicable dispute resolution mechanism that anticipates tiered dispute settlement including informal negotiation, mediation, and judicial proceedings. ${ }^{156}$

Regarding remedies, in addition to the remedial regimes that CDAs may provide, there are proposals to attach the enforceability of CDAs to primary state-investor contracts. In this regard, section 22 of the International Bar Association's Model Mine Development Agreement suggests that 'a material breach of the Community Development Agreement by the Company, shall constitute a breach' of the investor-state mining agreement. ${ }^{157}$ Such provisions would create a different dynamic for CDAs in a manner that implicates government intervention in these arrangements.

CDAs are not the only existing form of investor-community agreements. In agricultural projects, landowners sometimes grant concessions to investors. ${ }^{158}$ This is partly due to the fact that, in parts of the world, individuals and communities hold title to land and they have the authority to permit investors to work the land. However, the state mostly holds title to subsurface natural resources in most parts of the world. In parts of Canada, few individuals retain title to subsurface oil and gas, permitting the grant of freehold oil and gas leases. ${ }^{159}$ Nevertheless, regardless of the nature of the leasea Crown lease/licence or freehold lease - the government regulates production.

As demonstrated in this section, investor-local community agreements are essential for legal accountability and responsibility in the extractive industries. While many of these agreements exist as CDAs that focus on benefit provision, some are wider instruments that address impacts to a larger extent. There remain opportunities to further expand these instruments to better address responsibility in the extractive industry. In our view, these agreements signal the beginning of the turn to contracts as remedial regimes.

\section{Investor-State-Local Community Contracts}

Tripartite agreements between investors, governments, and local communities are not common. However, they exist and serve important purposes especially for determining liability for extractive activities. These types of agreements are the epitome of contractual responsibility in natural resource extraction especially because of the diversity of the parties involved, the diversity of the interests represented, and the inherently public law nature of these contracts. They immediately transport the conversation beyond private law notions of contract law.

Tripartite agreements between states, investors, and local communities exist in the form of environmental agreements in Canada. ${ }^{160}$ The environmental contract formed

\footnotetext{
155 'Argyle Diamond Mine Participation Agreement', note 112.

156 Ibid.

157 MMDA, note 39.

158 Cotula, note 39, 3.2, para. 25. Cotula cites some examples including 'a 2008 land lease between Mondi Ltd, a South African timber company, and the Siyathokoza Community Trust in South Africa' and another agreement between an Indian company and ' 13 associations of local landholders' in Madagascar.

159 John Bishop Ballem, The Oil and Gas Lease in Canada (Toronto: University of Toronto Press, 2008); Alastair R Lucas and Constance D Hunt, Oil and Gas Law in Canada (Toronto: Carswell, 1990).

160 See the discussion in footnotes 54-61 and the accompanying text.
} 
between the Government of the Northwest Territories (Canada), local communities and De Beers Canada Inc. is an apt example. ${ }^{161}$ Some CDAs also take the form of tripartite arrangements between governments, investors, and local communities. Tripartite agreements between governments, investors, and local communities may also exist as exploration agreements ('exploration contract conditions'). As part of the agreements formed with indigenous communities, the Government of South Australia makes provisions for exploration agreements between the government, native title claim groups, and 'explorers'. ${ }^{162}$ While there are ample examples of tripartite environmental and social agreements, investment contracts that involve states, investors, and local communities are seldom used. An example of a joint venture agreement that involves all three actors is South Africa's Richtersveld Pooling Sharing Joint Venture between the government of South Africa, Alexkor (a diamond mining company owned by the state), and the community of Richtersveld. ${ }^{163}$

Tripartite contracts are acknowledgments of the important relationships among investors, governments, and local communities. They demonstrate recognition of the unique and essential roles that each of these actors play. The extent to which they could be widely adopted is yet to be seen.

\section{Conclusion: Strengths and Limits of Contemporary Contractual Regimes In the Extractive Industry}

Contracts are effective as instruments for tailoring responsibilities or fashioning accountability mechanisms as much as serving their traditional role of regulating technical and financial aspects of extractive industry projects. In addition, it is not unusual, as we have seen in this article, for extractive industry projects to come with environmental contracts that involve states, investors, and local communities. In one instance, we cited a unilateral undertaking by a corporation that arguably established an accountability mechanism for adverse human rights impacts regarding the Baku-TbilisiCeyhan project. In addition, we saw how contemporary PSCs include investor obligations to protect navigation and fishing, prevent pollution, and provide compensation for injury to private property or other losses or damages caused by corporate activity. On their part, CDAs in the extractive industry context have involved local communities, the state, and investors in a broad array of initiatives including investor-local community relations providing a framework for investments in local education, health, and other areas. ${ }^{164}$ While these newer contractual forms are relatively more established on environmental issues, they are nonetheless moving the needle

\footnotetext{
161 'Snap Lake Environmental Agreement', note 58.

162 See, e.g., 'ALMAC Exploration Contract Conditions (Schedule 2 to Framework ILUA)', http://ccsi.columbia.edu/ files/2015/01/Australia-Antakirinja-Native-Title-Group-SACOME-2003-Template-Contract-Conditions.pdf (accessed 2 August 2015).

163 Cotula, note 39, box 3; Paul G McHugh, Aboriginal Title: The Modern Jurisprudence of Tribal Land Rights (Oxford: Oxford University Press, 2011) 200. See also Department of International Relation and Cooperation, South Africa, 'Statement on the Cabinet Meeting' (08 August 2007), http://www.dfa.gov.za/docs/2007/cabinet0808.html (accessed 2 August 2015).

164 Dwight Newman, Natural Resource Jurisdiction in Canada (Toronto: LexisNexis, 2013) 99-101, arguing that there are potential benefits from appropriately constructed IBAs for industry and Aboriginal communities.
} 
forward in establishing accountability and responsibility mechanisms that did not exist before. This is important new groundwork for continuing to consolidate the progress so far, so that these new frameworks and mechanisms can be used effectively for human rights accountability.

These newer types of contractual forms demonstrate the malleability of contracts to serve different ends-the technical and financial interests at the centre of state and investor relations, and also the broader array of contingencies including environmental, social, and human rights impacts of extractive industry activities. The examples we have used in this article show that contracts can be designed to provide remedies that are appropriate to the situation of all the parties involved in extractive industry activities. Contracts are emerging as an option for responding to issues most important to the specific parties that other regimes cannot readily provide. Nevertheless, contracts are not without limitation. ${ }^{165}$ As we have shown, the idea that consent is the exclusive lens through which to view contract law is contested, as this narrow conception underestimates other goals of contract law. Today, contracting for natural resources must be understood in light of the touchstone concerns of human rights and environmental stewardship rather than be guided by outdated notions of consent. The variety of extractive industry contracts discussed in this article, especially those that involve indigenous communities, sometimes involves marriages of different legal traditions, and demonstrates how extractive industry activities are related to lived realities of those whom they impact. This article is an initial step towards developing a framework to navigate and negotiate these traditions in the extractive industry context.

However, contracts may not always sufficiently address many of the issues that impact on third parties and when they do, some of the language adopted in drafting the relevant provisions poses challenges of interpretation and enforceability. ${ }^{166}$ Relying exclusively on contracts as classically understood as the primary mode of private ordering in the extraction of natural resources is limited because such a view is abstracted from the broader social, environmental, and human rights context in which these activities occur. That is why in this article we focus on newer forms of contracts that embody a broader view of all the stakes and actors involved in the extraction of natural resources. In short, we favour more holistic contracts that account for this larger context.

We acknowledge that even while newer contractual forms account for a much broader context, this sometimes comes at a cost. For example in many CDAs, local communities often trade some rights for the benefits that they receive under these contracts. In Canada, indigenous peoples often exchange legally-recognized rights for economic benefits and other mitigation of the negative impacts of projects. ${ }^{167}$ The Pinehouse IBA — an agreement between local communities and two mining companies (Cameco and Areva)—requires

\footnotetext{
165 See Odumosu-Ayanu, note 105, 499-500. For a critique of Canada's IBAs, see Emilie Cameron and Tyler Levitan, 'Impact and Benefit Agreements and the Neoliberalization of Resource Governance and Indigenous-State Relations in Northern Canada' (2014) 93 Studies in Political Economy 23.

166 See, e.g., 'Uganda Model PSA 1999', note 94, Art 22.4(a), which states that the Licensee shall 'conduct the Petroleum Operations in a manner likely to promote the conservation of the natural resources of Uganda and the protection of its environment' (emphasis added). See also 'Mozambique Model Concession Contract 2006', note 94, Art 18.2, noting that 'the Concessionaire shall endeavour to utilize citizens of the Republic of Mozambique having appropriate qualifications to the maximum extent possible at all levels of its organization ...' (emphasis added).

167 Caine and Krogman, note 145, 80.
} 
community support for existing operations and proposed projects and any opposition to the issuance of authorizations for proposed projects will amount to a breach of the agreement. $^{168}$ The Pinehouse Agreement was also 'entered into in full and final satisfaction of any claim' by the communities against the companies 'for any infringement of Aboriginal rights by the Operations'. ${ }^{169}$

In addition, some of the more socially-inclined agreements, especially CDAs, are essentially risk-management mechanisms for the investors. Many CDAs are not instances of free, prior, and informed consent. ${ }^{170}$ While the 'free' and 'informed' aspects of consent may be more difficult to determine, many CDAs are clearly not formed 'prior' to the approval of extractive industry projects. In fact, many are formed years after the projects have been on stream. The GMOUs in Nigeria provide an example of this phenomenon. These CDAs thus become an avenue for investors to protect their investment by minimizing 'risk and potential downstream project delays ${ }^{\text {' }}{ }^{171}$ by seeking to establish cordial relationships with communities even if this came after some initial challenges. ${ }^{172}$ Nevertheless, contracts remain a potential platform for operationalizing free, prior and informed consent. The question that remains is the form that such contracts should take. Clear (legislative) mandates regarding the operationalization of free, prior, and informed consent may better define and address some of these questions.

Further, regardless of the form that these newer types of contracts take, most are not subject to legislative and public scrutiny. As a result, there is the potential to form agreements that may not be beneficial to the larger public. Hence, as noted earlier in this article, transparency is essential.

Finally a contract approach to responsibility in extractive industries, especially for actors like local communities, raises issues of neo-liberalization of resource governance or what some refer to as "market based solutions to social problems'. ${ }^{173}$ For many indigenous communities, self-determination remains one of the main themes that drive relationships with governments as well as investors. ${ }^{174}$ Hence, it is necessary to explore the relationship between self-determination and neo-liberalization in developing and assessing contractual responsibility in the extractive industry. ${ }^{175}$ Ironically, it may be the case that negotiated contracts are a greater reflection of self-determination than is immediately apparent.

In conclusion, regardless of their limitations, it is clear that there is a turn to contractual responsibility in the extractive industry. Contracts have been part of the life of

\footnotetext{
168 'Pinehouse Agreement', note 147, sec 5.1.

169 Ibid, sec 5.1(c).

170 UN General Assembly, 'United Nations Declaration on the Rights of Indigenous Peoples', GA Res 61/295 (13 September 2007), Art 32(2) ('UNDRIP').

171 Courtney Fidler and Michael Hitch, 'Impact Benefit Agreements: A Contentious Issue for Environmental and Aboriginal Justice' (2007) 35 Environments Journal 49, 57.

172 Caine and Krogman, note 145, 85.

173 See Cameron and Levitan, note 165, 40. See also Fiona Macdonald, 'Indigenous Peoples and Neoliberal "Privatization" in Canada: Opportunities, Cautions and Constraints' (2011) 44 Canadian Journal of Political Science 257; Cathy Howlett et al, 'Neoliberalism, Mineral Development and Indigenous People: A Framework for Analysis' (2011) 42 Australian Geographer 309.

174 See UNDRIP, note 170, Arts 3 and 4.

175 On neo-liberalism and indigenous self-determination, see Gabrielle Slowey, Navigating Neoliberalism: SelfDetermination and the Mikisew Cree First Nation (Vancouver/Toronto: University of British Columbia Press, 2008).
} 
oil, gas, and mining for a long time and in spite of the proliferation of investment treaties for protecting foreign investors and soft norms for addressing corporate responsibility, contracts have remained essential. That recognition is now being extended to the determination of responsibility to actors other than states and investors. While we have acknowledged the limitations of contemporary uses of the contractual form to fashion accountability and responsibility frameworks for investors to local communities and peoples, we nevertheless have demonstrated their potential. We strongly believe in the potential to use these contractual forms beyond their embryonic stages in providing remedial mechanisms for addressing adverse human rights, safety, health, or environmental impacts or as a framework for ensuring investments in local education, health, and other areas. The task ahead is to develop more robust contracts or arrangements and relationships akin to contracts, or to use contractual forms that provide enforceable remedial opportunities for those adversely impacted by natural resource extraction. 